\title{
Pearl Millet Bio-fortified Hybrid: GHB 1129
}

\author{
K.D. Mungra*, J.S. Sorathiya, S.K. Parmar, H.J. Vansjaliya and S.N. Galani \\ Pearl Millet Research Station, Junagadh Agricultural University, Jamnagar 361006 \\ (Gujarat), India
}

*Corresponding author

\begin{tabular}{|l|}
\hline Ke y w o r d s \\
$\begin{array}{l}\text { Pearl millet, } \\
\text { Downey mildew } \\
\text { and Biofortification }\end{array}$ \\
\hline Article Info \\
\hline $\begin{array}{l}\text { Accepted: } \\
\text { 15 June } 2019 \\
\text { Available Online: } \\
\text { 10 July } 2019\end{array}$ \\
\hline
\end{tabular}

\section{A B S T R A C T}

The earlier released hybrid GHB 558 and latest released hybrid GHB 732 become susceptible to downy mildew disease. Though recently released hybrid GHB 732 is popular but it is susceptible to lodging because of its thin stem. However, in view of versatility of downy mildew fungi for its changes in virulence, farmer based choice differences in different pearl millet growing area of the state and to diversify the genetic base of cultivated public bred pearl millet hybrids. There is an urgent need and demand for a medium duration kharif hybrid with downy mildew and lodging resistance. The hybrid GHB 1129 has got attractive seed colour, acceptable seed size, appealing ear head, downy mildew resistance and high grain yield potential as compare to check hybrids. Hence, it is recommended for general cultivation during the kharif (medium maturing) and summer seasons as a biofortified hybrid in Gujarat state with high yield and good quality parameter Fe and $\mathrm{Zn}$.

\section{Introduction}

Pearl millet is a climate smart crop by itselfdryland resilient with high metabolizable energy, high gluten-free protein, and more balanced amino acids. The inadequate intake of energy-providing organic macronutrients (largely carbohydrate, followed by protein and fat, in that order), leads to under-nutrition, with a consequent feeling of hunger (Webb et al., 2018). Unlike the macronutrients mentioned above, which are consumed in larger quantities for proper growth and development, there are several micronutrients which are needed in trace amounts, but they play vital roles in various physiological functions.

Iron and zinc deficiencies are widespread and serious public health problems worldwide, including India (Kramer et al., 2015). Biofortification is scientifically proven to be a sustainable and cost-effective approach to address malnutrition. This approach targets the root cause of the malnutrition. Looking to this alarming situation, the ICAR-AICRP on Pearl 
Millet has already decided on a minimum of $42 \mathrm{ppm}$ of iron and zinc $32 \mathrm{ppm}$. Any variety or hybrids to be sold to farmers by public or private seed producers should follow these micronutrient standards, apart from giving a higher yield (Anonymous, 2018).

None of the presently Gujarat state recommended hybrids have more than $70 \mathrm{ppm}$ Fe and $30 \mathrm{ppm} \mathrm{Zn}$. Looking to above facts, the work on development of high $\mathrm{Fe}$ and $\mathrm{Zn}$ content hybrids has been intensified at pearl millet research station, JAU, Jamnagar in collaboration with ICAR and ICRISAT and which resulted in to GHB 1129, a High Fe and Zn content hybrids which has been released at state level both for kharif and summer season cultivation.

\section{Material and Methods}

The pearl millet hybrid GHB 1129 is developed at Junagadh Agril. University, Jamnagar (Gujarat) from cross combination of ICMA 99222 x J-2565 female line ICMA 99222 is developed at ICRISAT and it is a identified high $\mathrm{Fe}$ and $\mathrm{Zn}$ content line. The restorer line J-2565 is developed at Pearl Millet Research Station, JAU, Jamnagar and its pedigree is ( $\mathrm{J}-2340 \times \mathrm{J}-2480)-8-5-6-2-2-1-$ $\mathrm{B}-\mathrm{B}$ and designated in the year 2012. The hybrid GHB 1129 has been tested from 2013 to 2018 during kharif and 2014 to 2018 during summer season at various testing location of Gujarat. It has been also tested as a MH-2118 at national level under AICRP trials during kharif 2015-16 at 27 different locations of Zone $\mathrm{A}$ and $\mathrm{B}$ of India and during kharif 2016-17 at 12 different locations of zone B. During kharif and summer seasons trials at state and national level this hybrid has been tested against recommended state and national level yield and biofortified checks. The recommended package of practices were followed to conduct the trial and to raise the good crop.

\section{Results and Discussion}

The GHB 1129 is a medium maturing biofortified hybrid which has given higher average grain yield over presently recommended relevant group checks GHB $744(8.0 \%)$, latest relevant group hybrid GHB $905(6.9 \%)$ and private sector relevant group check hybrid 86M11(20.1\%) during kharif season. The dry fodder increase of GHB 1129 over relevant group checks during kharif season was to the tune of $12.9 \%, 11.7 \%$ and $30.0 \%$ over GHB 744, GHB 905 and 86M11, respectively (Table 1). In the summer season this hybrid has also given $15.7 \%$ and $7.3 \%$ higher grain and dry fodder yield, respectively over GHB 558 and at par grain and $6.2 \%$ higher dry fodder yield over GHB 732. Moreover, the grains of this hybrid have higher amount of micronutrient $\mathrm{Fe}$ and $\mathrm{Zn}$ over all the public and private sector check and comparable $\mathrm{Fe}$ and $\mathrm{Zn}$ with biofortified check variety Dhanshakti (Table 2 and 3 ).

This hybrid also tested during kharif 2015-16 and 2016-17 in AICRP-PM trials as a testing code MH 2118. During first year 2015-16 testing in IHT-Medium (A/B) trial, it has given marginal higher yield over checks in Azone but in B (Southern India) zone it has given $9.61 \%, 19.42 \%$ and 30.38 higher yield over private sector checks NBH 5767, PAC 909 and public sector check GHB 558, respectively and promoted to second year testing in B zone. In second 2016-17 AHT(M) trial it has given $9.56 \%, 9.15 \%$ and $5.05 \%$ higher grain yield over private sector check hybrids PAC 909, Pratap and public sector check hybrid GHB 558, respectively. The dry fodder yield of proposed hybrid was higher than check hybrids PAC 909, GHB 558 and Pratap during its testing period under B zone. This hybrid found resistance against downey mildew when tested under sick plot condition at different locations during kharif (Table 4) and summer season (Table 5). 
Table.1 Grain and dry fodder yield data in large scale hybrid trial

\begin{tabular}{|c|c|c|c|c|c|}
\hline $\begin{array}{l}\text { Name of check } \\
\text { hybrid }\end{array}$ & $\begin{array}{l}\text { No of } \\
\text { trials }\end{array}$ & $\begin{array}{l}\text { Average grain } \\
\text { yield (kg/ha) }\end{array}$ & $\begin{array}{l}\% \\
\text { increase } \\
\text { over check }\end{array}$ & $\begin{array}{l}\text { Average dry fodder } \\
\text { yield (kg/ha) }\end{array}$ & $\begin{array}{l}\% \text { increase } \\
\text { over check }\end{array}$ \\
\hline \multicolumn{6}{|l|}{ Kharif (2013-18) } \\
\hline GHB 1129 & 47 & 2957 & & 6210 & \\
\hline GHB 1129 & 43 & 3012 & & 6350 & \\
\hline GHB 1129 & 8 & 3059 & & 7225 & \\
\hline GHB 744 (c) & 47 & 2739 & 8.0 & 5502 & 12.9 \\
\hline GHB 905 (c) & 43 & 2817 & 6.9 & 5685 & 11.7 \\
\hline 86M11 (c) & 8 & 2546 & 20.1 & 5557 & 30.0 \\
\hline \multicolumn{6}{|c|}{ Summer (2014-18) } \\
\hline GHB 1129 & 20 & 5303 & & 9179 & \\
\hline GHB 1129 & 4 & 5610 & & 8441 & \\
\hline GHB 558 (c) & 20 & 4583 & 15.7 & 8557 & 7.3 \\
\hline GHB 732 (c) & 20 & 5409 & - & 8645 & 6.2 \\
\hline 9444 (c) & 4 & 5701 & - & 9262 & - \\
\hline Nandi 72 (c) & 4 & 6041 & - & 8929 & - \\
\hline
\end{tabular}

Table.2 Data on Fe and Zn content of GHB 1129 against checks hybrids during kharif

\begin{tabular}{|l|c|c|c|c|c|c|c|c|}
\hline Hybrid & \multicolumn{4}{|c|}{ Fe Content $(\mathbf{p p m})$} & \multicolumn{4}{c|}{ Zn Content (ppm) } \\
\hline & $\mathbf{2 0 1 6}$ & $\mathbf{2 0 1 7}$ & $\mathbf{2 0 1 8}$ & Mean & $\mathbf{2 0 1 6}$ & $\mathbf{2 0 1 7}$ & $\mathbf{2 0 1 8}$ & Mean \\
\hline GHB 1129 & 71 & 72 & 74 & $\mathbf{7 2}$ & 35 & 48 & 45 & $\mathbf{4 3}$ \\
\hline GHB 744 (C) & 47 & 59 & 53 & $\mathbf{5 3}$ & 37 & 32 & 29 & $\mathbf{3 3}$ \\
\hline GHB 905 (C) & 44 & 46 & 46 & $\mathbf{4 5}$ & 40 & 32 & 34 & $\mathbf{3 5}$ \\
\hline Dhanshakti $(\mathbf{C})$ & 90 & 88 & 96 & $\mathbf{9 1}$ & 47 & 32 & 43 & $\mathbf{4 1}$ \\
\hline 86M11 $(\mathbf{C})$ & & & 65 & $\mathbf{6 5}$ & & & 34 & $\mathbf{3 4}$ \\
\hline
\end{tabular}

Table.3 Data on Fe and Zn of GHB 1129 in comparison with checks hybrids during summer (2016-2018)

\begin{tabular}{|l|c|c|c|}
\hline \multirow{2}{*}{ Quality character } & Proposed hybrid & \multicolumn{2}{|c|}{ Check hybrids } \\
\cline { 2 - 4 } & GHB 1129 & GHB 558 & GHB 732 \\
\hline Fe Content $(\mathrm{ppm})$ & 74 & 60 & 53 \\
\hline Zn Content $(\mathrm{ppm})$ & 33 & 25 & 22 \\
\hline
\end{tabular}


Table.4 The mean of reaction of disease in percentage under artificially epiphytotic condition during kharif 2013 to 2018 season at Jamnagar, Anand and S. K. Nagar

\begin{tabular}{|l|c|c|c|c|}
\hline Hybrid of hybrid & Downy mildew (\%) (60 DAS) & Blast (\%) & Smut (\%) & Rust (\%) \\
\hline GHB1129 & $0.63(0-2.6)$ & $15.97(0-31)$ & $4.38(0-14)$ & $16.60(0-59)$ \\
\hline GHB744(c) & $4.34(0.6-11.5)$ & $13.29(0-28)$ & $1.21(0-6)$ & $14.49(0-39)$ \\
\hline GHB905(c) & $2.29(0-9.1)$ & $19.71(0-39)$ & $0.95(0-5)$ & $14.73(0-59)$ \\
\hline Dhanshakti(c) & $4.17(1.5-6.9)$ & $43.05(41-45)$ & 0.00 & 0.00 \\
\hline 86M11(c) & $3.69(3.7-3.7)$ & $11.67(11-11)$ & 0.00 & 0.00 \\
\hline 7042 S & 90.92 & 47.48 & 13.18 & 30.83 \\
\hline
\end{tabular}

Figure in parenthesis is range

Table.5 The mean of reaction of disease in percentage under artificially epiphytotic condition during summer 2014 to 2018 season at Jamnagar, Anand and S.K. Nagar

\begin{tabular}{|l|c|c|}
\hline Hybrid of hybrid & Downy mildew (\%) (60 DAS) & Rust (\%) \\
\hline GHB 1129 & $2.35(0-4)$ & - \\
\hline GHB 558 (c) & $5.76(2-13)$ & $2.1(0-8)$ \\
\hline GHB 732 (c) & $3.63(0-7)$ & $3.8(0-7)$ \\
\hline 9444 (c) & $2.40(0-5)$ & - \\
\hline Nandi 72 (c) & $2.43(0-6)$ & - \\
\hline Indicator line & 85.9 & - \\
\hline
\end{tabular}

Figure in parenthesis is range

Table.6 Data on grain quality parameter of proposed hybrid GHB 1129 in Comparison with checks

\begin{tabular}{|l|l|c|c|c|}
\hline Sr. No. & Hybrid of hybrid & Protein (\%) & Fat (\%) & Carbohydrate (\%) \\
\hline $\mathbf{1}$ & GHB 1129 & 9.27 & 6.21 & 70.48 \\
\hline $\mathbf{2}$ & GHB 744(C) & 9.87 & 5.90 & 64.41 \\
\hline $\mathbf{3}$ & GHB 905 (C) & 8.88 & 5.19 & 69.70 \\
\hline $\mathbf{4}$ & Dhanshakti(C) & 9.17 & 5.88 & 68.64 \\
\hline $\mathbf{5}$ & 86M11 (C) & 8.83 & 4.92 & 70.66 \\
\hline
\end{tabular}

Table.7 Data on dry fodder quality characteristics of GHB 1129 with checks hybrids (On DM basis)

\begin{tabular}{|l|l|c|c|c|c|c|c|}
\hline $\begin{array}{l}\text { Sr. } \\
\text { No. }\end{array}$ & $\begin{array}{l}\text { Hybrid } \\
\text { hybrid }\end{array}$ & $\begin{array}{c}\text { Crude } \\
\text { Protein (\%) }\end{array}$ & $\begin{array}{c}\text { Crude } \\
\text { Fat (\%) }\end{array}$ & $\begin{array}{c}\text { Crude } \\
\text { Fiber }(\boldsymbol{\%})\end{array}$ & $\begin{array}{c}\text { Total } \\
\text { Ash (\%) }\end{array}$ & $\begin{array}{c}\text { NFE } \\
(\boldsymbol{\%})\end{array}$ & $\begin{array}{c}\text { IVDMD } \\
(\boldsymbol{\%})\end{array}$ \\
\hline $\mathbf{1}$ & GHB 1129 & 3.74 & 0.55 & 43.90 & 6.77 & 45.04 & 53.18 \\
\hline $\mathbf{2}$ & GHB 744(C) & 4.34 & 1.29 & 47.76 & 11.00 & 35.61 & 57.09 \\
\hline $\mathbf{3}$ & GHB 905 (C) & 4.41 & 1.33 & 46.31 & 10.04 & 37.91 & 54.91 \\
\hline $\mathbf{4}$ & Dhanshakti(C) & 4.53 & 1.17 & 43.43 & 7.77 & 43.10 & 55.60 \\
\hline $\mathbf{5}$ & 86M11 (C) & 5.20 & 0.73 & 47.73 & 6.25 & 40.09 & 49.87 \\
\hline
\end{tabular}


Table.8 Distinguish morphological traits descriptions of proposed hybrid GHB 1129 along with latest check GHB 905 as per DUS guidelines

\begin{tabular}{|c|c|c|c|}
\hline Sr. & Characters & GHB 1129 & GHB 905 \\
\hline 1 & $\begin{array}{l}\text { Plant anthocynin pigmentation of } 1^{\text {st }} \\
\text { leaf sheath }\end{array}$ & Absent & Absent \\
\hline 2 & Plant growth habit (30 DAS) & Erect & Erect \\
\hline 3 & Time of spike emergence (Days) & Medium & Early \\
\hline 4 & Leaf sheath pubescence & Absent & Absent \\
\hline 5 & $\begin{array}{l}\text { Leaf sheath length }(\mathrm{cm}) \text { (Forth leaf } \\
\text { from top) }\end{array}$ & Medium & Medium \\
\hline 6 & Leaf length (cm) (Forth leaf from top) & Very long & Medium \\
\hline 7 & Leaf width $(\mathrm{cm})$ (Forth leaf from top) & Broad & Medium \\
\hline 8 & Anther colour & Yellow & Yellow \\
\hline 9 & Node pubescence & $\begin{array}{l}\text { Present in upper two } \\
\text { nodes }\end{array}$ & Absent \\
\hline 10 & Number of node on main stem & Medium & Low \\
\hline 11 & Node Pigmentation & Green & Green \\
\hline 12 & Internode pigmentation & Green & Green \\
\hline 13 & Spike Exertion & Complete & Complete \\
\hline 14 & Spike length (cm) & Medium & Medium \\
\hline 15 & Anthocynin pigmentation of glume & Absent & Absent \\
\hline 16 & Bristles presence & Absent & Present \\
\hline 17 & Bristle colour & NA & Brown \\
\hline 18 & Spike diameter $(\mathrm{cm})$ & Thick & Medium \\
\hline 19 & Spike shape & Cylindrical & Cylindrical \\
\hline 20 & No. of effective tillers per plant & Low & Medium \\
\hline 21 & Plant height(excluding spike) (cm) & Medium tall & Short \\
\hline 22 & Spike tip sterility & Absent & Absent \\
\hline 23 & Spike density & Compact & Semi-compact \\
\hline 24 & Seed colour & Grey brown & Grey brown \\
\hline 25 & Seed shape & Globular & Globular \\
\hline 26 & 1000- grain weight (g) & Medium & Medium \\
\hline
\end{tabular}




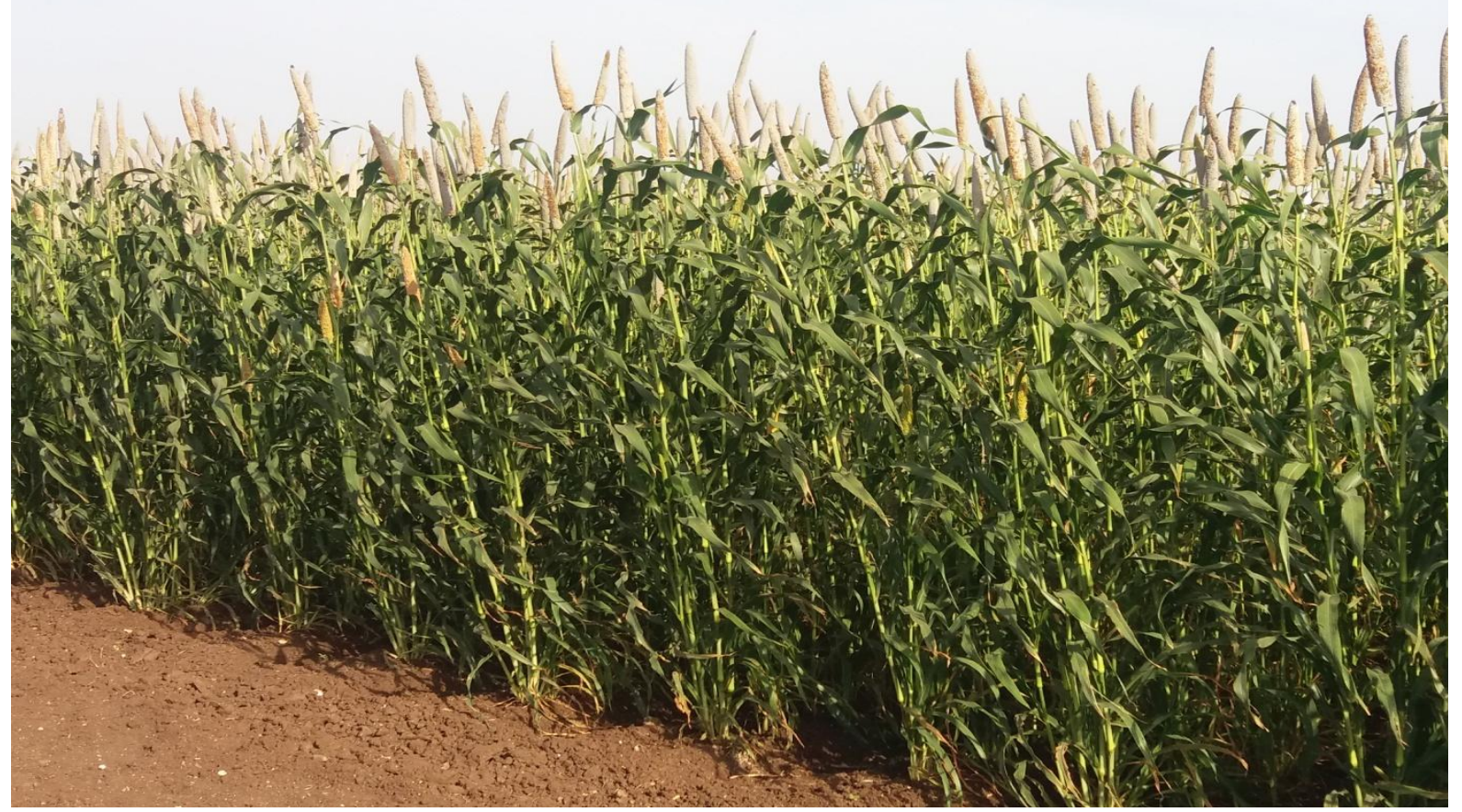

Field View of Bio-fortified pearl millet hybrid GHB 1129

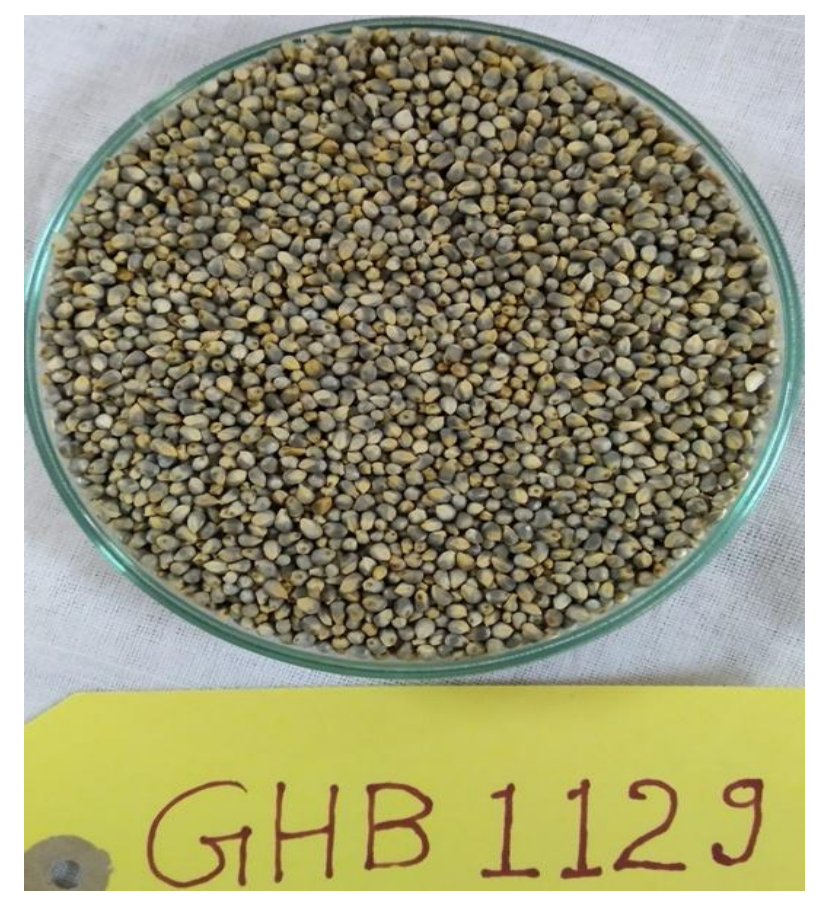

Grains of Bio-fortified pearl millet hybrid GHB 1129

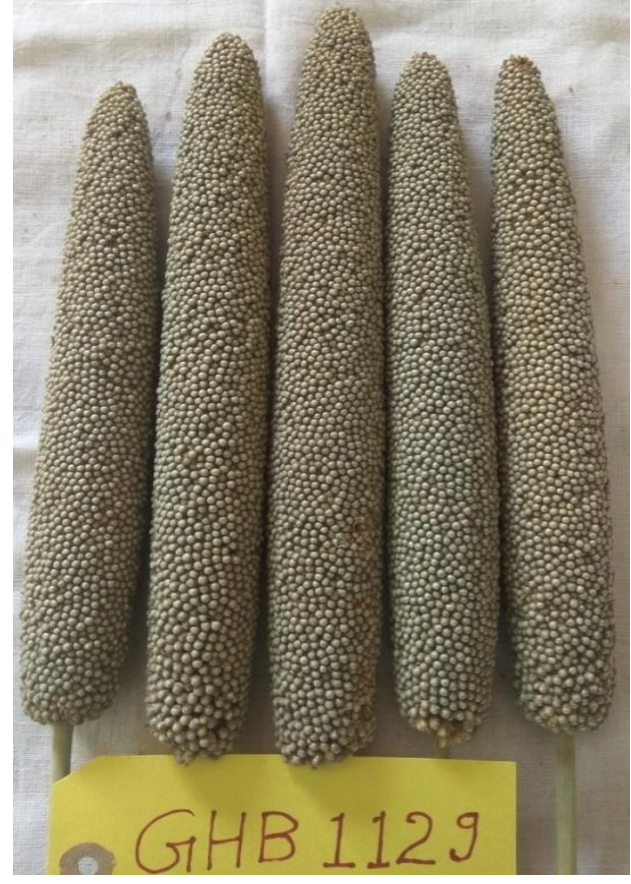

Panicles of Bio-fortified pearl millet hybrid GHB 1129
This hybrid also found resistance against Blast, Smut and rust. The ergot disease was not observed during its testing period. It is also found more resistance against shoot fly $(3.6 \%)$ and stem borer $(1.4 \%)$ and Helicoverpa (1.5 larva/5 earhead) as 
compared to checks. Further, this hybrid also found resistance against lodging when tested against its checks during both the season.

The quality parameter test of grain (Table 6) and dry fodder (Table 7) indicated that, this hybrid possess good or comparable quality parameters when tested against its checks.

The organoleptic quality parameters evaluation of pearl millet chapatti of GHB 1129 was carried out against all its checks by taking the response from 22 respondents. The result indicated that the overall $1^{\text {st }}$ preference recorded by GHB 1129 against all its check.

The mean ancillary data suggest that this hybrid flower in average 48 days and mature in 80 days, average plant height is $186 \mathrm{~cm}$, the average number of tillers are 2.5 per plant. The average earhead length, girth and test weight is $21.3 \mathrm{~cm}, 3.0 \mathrm{~cm}$ and $8.8 \mathrm{~g}$, respectively. The distinguish morphological traits of GHB 1129 as per the DUS guidelines in comparison with latest check GHB 905 are mentioned in Table 8.

\section{References}

AICRP Pearl Millet. 2018. Proceedings of the 53rd Annual Group Meeting of ICAR All India Coordinated Research Project on Pearl Millet. Available online: http://www. http://aicpmip.res.in/ (accessed on 31 June 2019).

Kramer, C.V., Allen, S. 2015. Malnutrition in developing countries. Paediatr. Child Health, 25: 422-427.

Webb, P., Stordalen, G.A., Singh, S., Wijesinha-Bettoni, R., Shetty, P., Lartey, A. 2018. Hunger and malnutrition in the 21 st century. BMJ 2018, 361, k2238, doi: 10.1136/bmj.k2238

\section{How to cite this article:}

Mungra, K.D., J.S. Sorathiya, S.K. Parmar, H.J. Vansjaliya and Galani, S.N. 2019. Pearl Millet Bio-fortified Hybrid: GHB 1129. Int.J.Curr.Microbiol.App.Sci. 8(07): 1886-1892. doi: https://doi.org/10.20546/ijcmas.2019.807.224 